\title{
AKKUMULÁTOR CELLÁK KÖTÉSTECHNOLÓGIÁINAK IRODALMI ÁTTEKINTÉSE
}

\section{LITERATURE REVIEW OF BATTERY CELL JOINING TECHNOLOGIES}

\author{
Hareancz Ferenc ${ }^{1 *}$, Sztupinszky Zsolt ${ }^{2}$, Sinka Tamás ${ }^{1}$, \\ 1 Innovatív Járművek és Anyagok Tanszék, GAMF Műszaki és Informatikai Kar, Neumann János Egyetem, \\ Magyarország \\ 2 Videoton Elektro-PLAST Kft., Magyarország \\ https://doi.org/10.47833/2021.1.ENG.014
}

\section{Kulcsszavak: \\ hegesztés \\ ellenállás hegesztés \\ akkumulátor \\ kötéstechnológia \\ anyagtechnológia}

\section{Keywords:}

welding

resistance welding

battery

joining technology

materials technology

\section{Cikktörténet:}

Beérkezett 2021. április 20.

Átdolgozva 2021. május 5.

Elfogadva 2021. május 31.

\begin{abstract}
Összefoglalás
A hegesztés az egyik leghatékonyabb és leggazdaságosabb módszer a fémek összekapcsolására. Az ellenállás hegesztés az iparban az egyik leggyakrabban alkalmazott hegesztési technológiáik közé tartozik. Előnye, hogy a kötés létrehozásakor az összehegesztendö lemezek vastagsága minimálisan változik. $A z$ elektronikában is nagy szerepe van ennek a kötéstechnológiának. Az egyre nagyobb mértékü elektromobilitás egyre több és nagyobb méretű akkumulátorokat igényel, melyeket nagyszámú egymással összekapcsolt egyedi akkumulátorcellákból építenek Az akkumulátor cellák összekapcsolásával elektromos és mechanikai kapcsolatot létesitünk, melyet különböző technológiákkal valósíthatunk meg. Cikkünk jelen kötéstechnológiák témakörével foglalkozik. Célunk bemutatni a technológiák müködését és az ellenállás hegesztés sajátosságait.
\end{abstract}

Abstract
Welding is one of the most efficient and economical methods of
joining metals. Resistance welding is one of the most commonly
used welding technologies in industry. It has the advantage that
the thickness of the plates to be welded together varies minimally
when the joint is created. This joining technology has also of
great importance in electronics. Increasing electromobility
requires more and larger batteries, which are built from many
individual battery cells connected together. This article deals with
the present bonding technologies. The aim is to describe how the
technologies work and the specificities of resistance welding.

\section{Bevezetés}

Az akkumulátor cellák összekapcsolásával elektromos és mechanikai kapcsolatot létesítünk, melyeket különböző technológiákkal valósíthatunk meg. Ezek lehetnek oldható vagy oldhatatlan kötések. Az eltérő kötési technológiáknak megvannak a sajátosságai. Kötőelemes oldható kötés esetében súly növekedéssel és magas kötési ellenállással kell számolni. Ezzel szemben egy

\footnotetext{
* Kapcsolattartó szerző. Tel.: +36 76516 367;

E-mail cím: hareancz.ferenc@gamf.uni-neumann.hu
} 
hegesztett kötés esetében nincs súly növekedés és a kötés ellenállása is sokkal alacsonyabb $[1,2,3,4]$.

Ezen következtetésekböl a cellák összekötését legtöbbször hegesztéssel végzik, erre mutat példát az 1. ábra is. A hegesztett kapcsolatot különböző módon lehet létrehozni. $A z$ akkumulátoroknál esetében a legelterjedtebb technológiák az ultrahangos hegesztés, lézersugaras hegesztés, mikro TIG hegesztés és az ellenállás hegesztés.

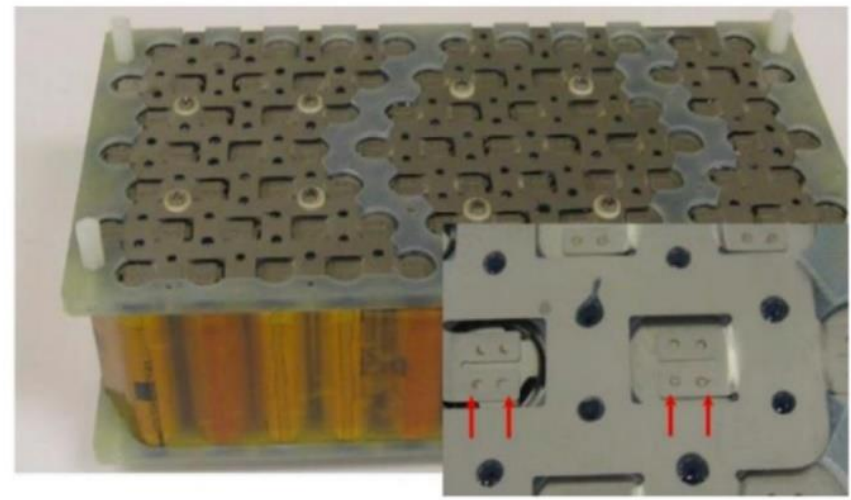

1. ábra: Egyoldali ellenállás-ponthegesztés: Vezető lemez hegesztése akkumulátor cellákra [1]

Az ellenállás hegesztés az iparban az egyik legnagyobb mértékben alkalmazott hegesztési technológia. A vékonylemezeket túlnyomó részt ellenállás hegesztéssel egyesítik, mivel a többi eljárással összehasonlítva ez a legtöbb mérnöki és gazdasági előnnyel rendelkező kötéstípus. Azonban az akkumulátor esetében kétoldali ellenállás hegesztési technológia az akkumulátorok rövidzárása miatt nem lehetséges. A csalatkozó elemek hegesztése egyoldali ellenállásponthegesztéssel történik [5].

\section{Akkumulátor cellák kötéseinek eljárásai}

A mai ipari környezetben hatalmas igények vannak a nagy energiájú akkumulátor összeállításokra. Ezzel együtt el szeretnék érni azt, hogy a rendszer a lehető legmegbízhatóbb legyen és persze mindemellett termelékeny és költséghatékony is maradjon. A lehető legkedvezőbb rendszer megtalálása érdekében érdemes néhány technológiát áttanulmányozni, mivel az egyes kötésekkel szemben számos elvárás van. Fontos követelmények, hogy a kötéseknek alacsony elektromos ellenállással kell rendelkezniük és a lehető legkisebb höbevitellel kell létrehozni megfelelő szilárdság mellett - a cellák hőérzékenysége miatt. Természetesen a nagyvolumenű gyártás miatt a gazdasági szempontokat is figyelni kell $[1,5,6]$.

\subsection{Ultrahangos hegesztés}

Az átlapolt kötések létrehozásának egyik gyakran alkalmazott eljárása az ultrahangos hegesztés. Az eljárás alapja, hogy az érintkező felületeket $20 \mathrm{kHz}$-nél nagyobb frekvenciájú rezgéssel mozgatjuk nyomó erő alkalmazása mellett. A fellépő súrlódás miatt hő keletkezik és az egyidejü képlékeny alakváltozás hatására az elemek között szilárd fázisban kötés jön létre. Ebböl fakadóan az egyik hatalmas elönye a kiváló kötésminőség abban az esetben, ha több rétegben vékony jó vezetőképességủ anyagokat használunk, mint például a réz és az alumínium, elvi vázlata a 2. ábrán látható $[1,7]$. 

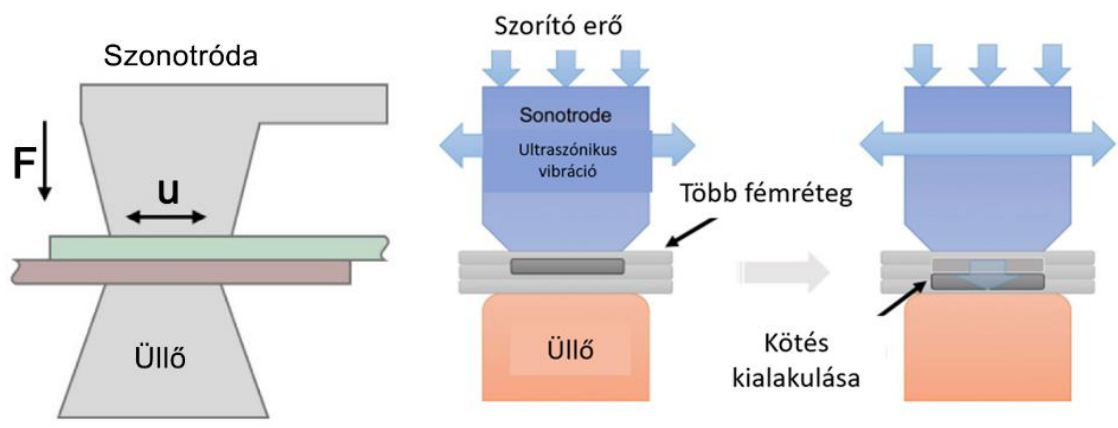

2. ábra: Ultrahangos hegesztés vázlata $[1,8]$

Az ultrahangos hegesztés nagyon vékony, megközelítőleg néhány mikronos kötést képes kialakítani. Az eljárás előnye, hogy más eljárásoknál előforduló metallurgiai hibáktól mentes. Ide értendő a porozitás, melegrepedés stb. Nagy általánosságban ezt a kötési módszert tartják a legjobbnak a Li-ion akkumulátorok kapcsolatainak kialakítására. Azonban korlátai között lehet említeni, hogy kétoldali hozzáférés szükséges, ezért a helyszükséglet miatt kimondottan prizmatikus cellák kötéseinek a kialakítására használják, valamint bármely rezgés kárt okozhat a cellákban. Azonban a más kötési eljáráshoz viszonyítva sokkal kisebb energiabefektetést igényel és a folyamat rövid időszükséglete miatt a cella höterhelése is alacsony $[1,7,8]$.

Az eljárásnál alkalmazható anyagok listája széleskörü, mivel mind jó hő és elektromos vezetőképességű, valamint nagy reflektivitású anyagokkal is képes kötést létrehozni. A technológia szük keresztmetszete a nagy ellenállás, mivel az áram a kis keresztmetszetű, kialakuló kötésen halad át [8].

\subsection{Lézersugaras hegesztés}

A lézersugaras hegesztés legnagyobb elönye abban rejlik, hogy kontaktus nélkül képes kötéseket létrehozni kis és nehezen hozzáférhető helyeken is. A lencséből kilépő fénysugár nagy koncentráltsága miatt nagy hőmennyiséget képes a felületre juttatni. Az ellenállás ponthegesztéshez képest nagyobb átmérőjü varratok kialakítására is képes és szintén nem igényel hozaganyagot. $A$ technológia elvi vázlatát a 3. ábra szemlélteti $[8,9]$.

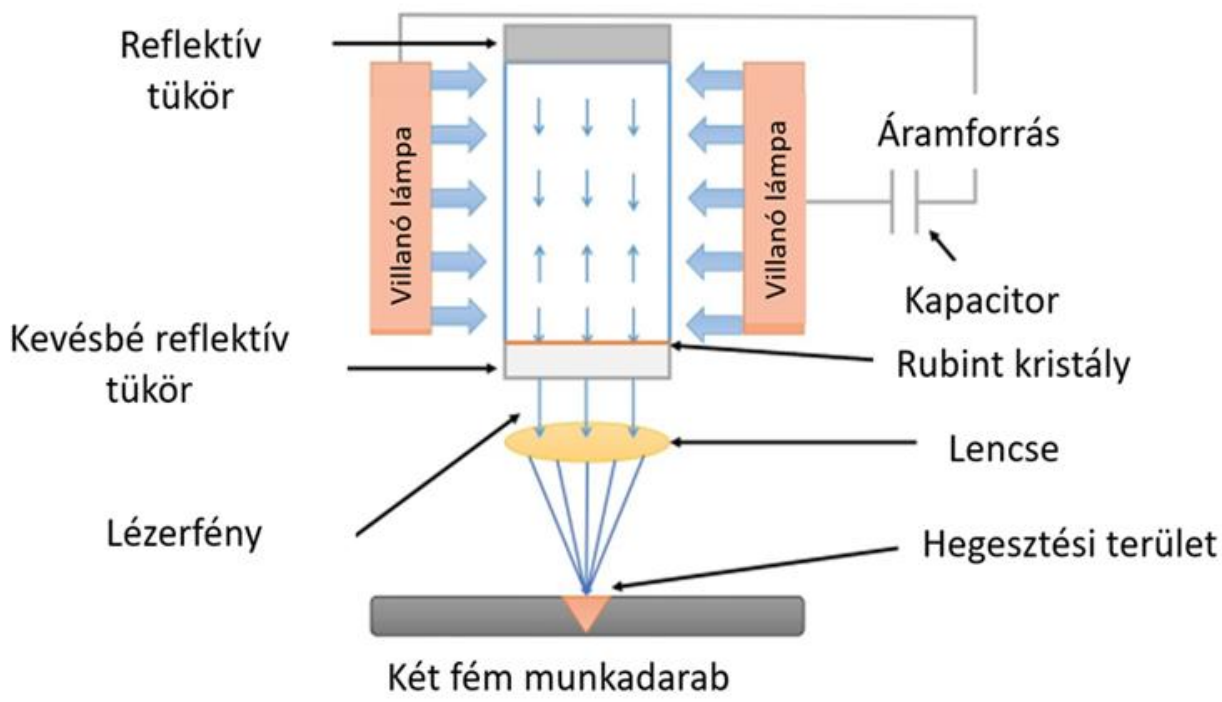

3. ábra: Lézersugaras hegesztés elvi vázlata [8]

A módszer egyik nagy korlátja egyfelöl, hogy a többi eljáráshoz viszonyítva nagyon komplex és ezért speciális képzettséget igényel. Másfelöl a felületekről visszaverődő fény és ezáltal az elnyelt hő mennyisége szignifikánsan megváltozhat [8]. 
Az akkumulátor cellák hegesztése során a gyakorlatban két féle sugárforrás terjedt el: a szállézer és a Nd:YAG lézerek. A reflektív anyagok használata esetén az impulzus üzemü lézerek vannak jelen az ipari környezetben. Ennek magyarázata az, hogy az energiát nagyon rövid impulzusok formájában juttatják be a darabba, így a müködés során a bejuttatni kívánt energia sokkal nagyobb mértékben nyelődik el, mint folyamatos üzem esetén. A korábban említett két forrás mindkét üzemmódban fellelhető a piacon, ezáltal a felépíthető rendszerek széles választékát képesek biztosítani $[8,10,11]$.

A hegesztés során létrejövő kötés minőségét számos paraméter együttese határozza meg. Ezek közül kiemelendő a teljesítmény, a hegesztési sebesség és az impulzus sürüség. A felsorolt paraméterek mind hatást gyakorolnak a varrat minőségére, a beolvadás mélységére és a varrat szélességére. A különbség csupán annyi a felsorolt változók között, hogy a teljesítményt változtatva a varrat méretei egyenes arányban változnak, míg a sebességet változtatva fordított viselkedést tapasztalunk [8].

A paraméterek jó beállításával könnyedén képesek vagyunk változtatni a vastag és vékony darabok kötéseinek kialakítását, valamint a varrat méretét [8].

Lézersugaras eljárás esetén a rövid impulzusok alkalmazásával eredményesen el lehet kerülni a nagy felmelegedést, hiszen a bejutatott hő szinte azonnal el is vezetődik, így a felmelegedés elhanyagolható. Kutatások kimutatták azt, hogy nagy energia használatával, illetve hosszú hegesztési folyamattal a cella kritikus hömérsékletre hevül. A Li-ion akkumulátorok esetén ez az érték $70{ }^{\circ} \mathrm{C}[4,8]$.

Ennek a technológiának a használatával kis kötések is létrehozhatók. Abban az esetben azonban, ha a létrejött kötés kisebb, mint a rajta átfolyó áram, akkor nőni fog az ellenállás. Ennek az ellenállásnak a növekedése folytán töltés, illetve merítés során melegedés lesz tapasztalható, amelynek köszönhetően az elem élettartama csökken $[4,8]$.

\subsection{Mikro TIG ponthegesztés}

Mikro TIG hegesztést az impulzus íves technológiák közé tartozik. Ezt a kötési technológiát hozaganyag adagolása nélkül vékony lemezek esetében alkalmazzák. A varratot egy néhány tíz milliszekundum ideig égő ívimpulzus hozza létre, ezáltal a hőbevitel sokkal kisebb, mint a hagyományos TIG hegesztés esetében (4. ábra). A kötések létrehozása általában egyenárammal történik nikkel, réz és acél vékony lemezek esetében, de alumínium esetében az oxid bontó hatás miatt váltóáramú ívet használnak $[1,12,13,14]$.
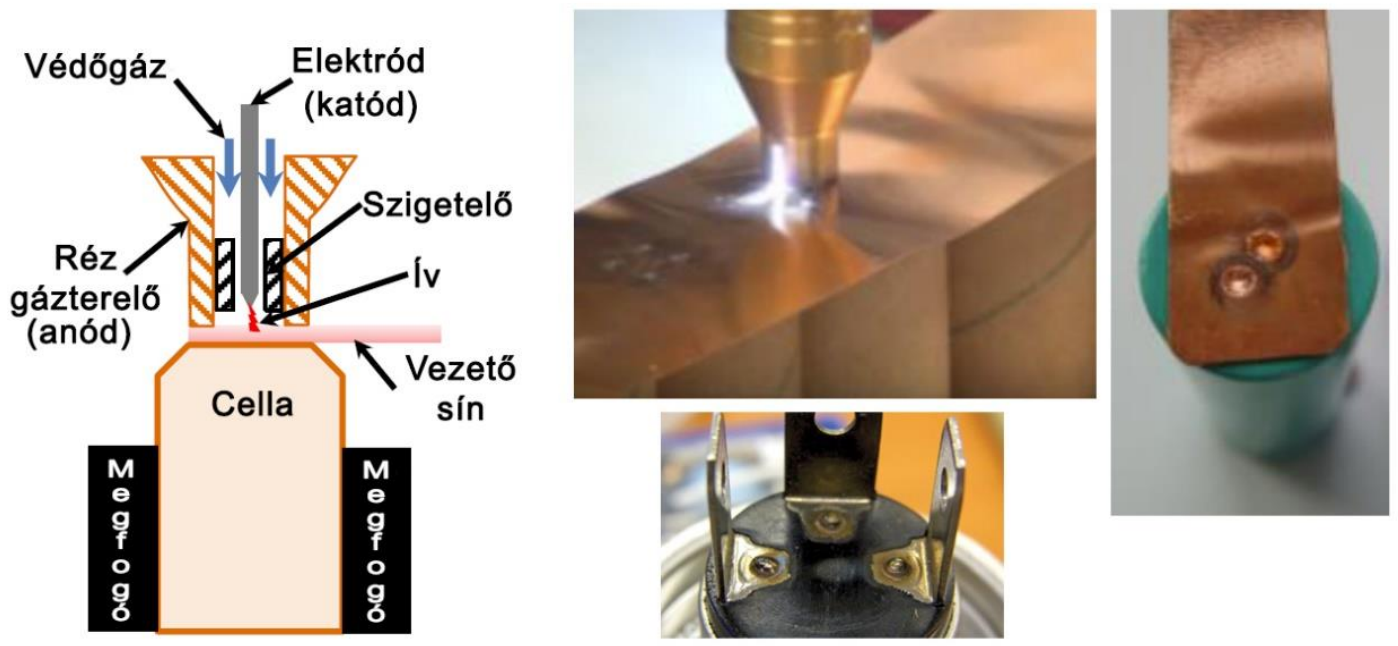

4. ábra.: Mikro TIG hegesztés vázlata és kötések

A szakirodalomban azonban nagyon kevés helyen olvasni a mikro TIG alkalmazásáról, különösen akkumulátor cellák hegesztése esetében. Az eljárás előnyei közé sorolható a jó kötés szilárdság, a kis elektromos ellenállás és a könnyű automatizálás. A kötés létrehozásához azonban védőgáz szükséges és a különböző anyagok hegesztése nehézkes. Sokkal elterjedtebb technológia az ellenállás ponthegesztés $[1,12,13,14]$. 


\subsection{Ellenállás ponthegesztés}

Az ellenállás ponthegesztés a legrégebb óta alkalmazott és széles körben elterjedt kötéstechnológia. A legnagyobb érvek ezen eljárás mellet, hogy semmilyen védőgáz, hozaganyag adagolása nem szükséges és könnyen automatizálható. Általánosságban elmondható az, hogy egy olcsó és gyors módszer, amely során jól szabályozhatóak a kötés minőségi jellemzői is. Az ellenállás hegesztés akkumulátor cellák hegesztésénél használt összeállitásra hoz példát az 5. ábra [8,9].

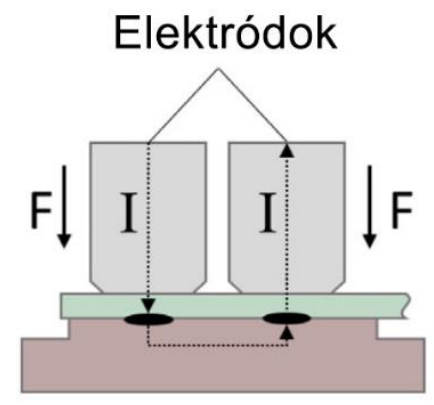

\section{5. Ábra: Ellenállás ponthegesztés elvi ábrája akkumulátor cellák hegesztése esetén [8]}

Hátrányai közé sorolható az, hogy jó vezető képességű anyagokat (pl. réz), illetve több réteget nehézkesen lehet vele összehegeszteni. A kötés tényleges minőségét nehéz meghatározni, akárcsak azt, hogy a kötés az összekötött darabok között hol jött létre. A technológia egyik jellegzetes hibája az elektróda feltapadás, amely során a hegesztett darab feltapad a kötés létrehozása során $[8,9]$.

Az ellenállás ponthegesztés során az egyik fontos szempont az elektróda anyagának megválasztása. Az elektróda anyagának a hegeszteni kívánt anyaghoz képest kisebb ellenállásúnak, jobb hővezetőnek, valamint megfelelő szilárdságúnak kell lennie. Ha szükséges, hütést alkalmazhatunk, hogy a túlmelegedéstöl megóvjuk az elektródákat. Az összetételtől függően három fö csoportba sorolhatjuk be őket:

- A csoport: Rézbázisú ötvözetek,

- B csoport: Nem rézbázisú ötvöztek és kompozitok (nagy hö és kopás állóság),

- C csoport: Speciális ötvözetek (ODS [Oxide Dispersion Strengthened] ötvözetek).

Általánosságban az első csoportba tartozó réz ötvözetek terjedtek el. Az akkumulátorokhoz rögzített csatlakozóknak az anyaga pedig acél, nikkel, réz vagy alumínium $[8,10]$.

A létrejövő kötés mérete számos tényező együttesétöl függ, amelyek az elektróda ötvözete és geometriája, a hegesztés időtartama, illetve a hegesztési áramerösség. Abban az esetben, ha a kötés készítése során beállított áram erőssége alacsony, vagy túl rövid ideig tart a ciklus, a darab nem fog megolvadni és nem jön létre a hegesztett kapcsolat. Az esetek többségében ezen két paraméter egyensúlyba hozásával lehet elérni az optimális méretet $[8,9]$.

A korábban felsorolt paramétereket kiegészítendően még szót kell ejteni az elektróda által kifejtett erőről és annak hatásáról. Abban az esetben, ha a felépülő nyomás nagysága elenyésző, illetve a ciklus lefutása is rövid nagy valószínüséggel hibás, nem megfelelő minőségű kötés alakul ki. Azonban, ha túlságosan nagy erővel és hosszabb időtartammal dolgozunk a fellépő nagy hő kárt tehet az elektródában és a munkadarabon égési nyomot hagy maga után [8].

Az alkalmazott hegesztő áram erősségének nagyságát érdemes az összeköttetendő darabok ellenállásához viszonyítva beállítani. A túl nagy áram jelenléte egyes esetekben repedések, illetve üreges rossz minőségű kötések kialakulásához vezethet, amelyek a kötés szilárdságára negatív hatással vannak [8].

A rövid ciklusidővel rendelkező ellenállás hegesztések a leggyakrabban a Li-ion akkumulátorok hegesztésénél használatos. Ezzel a típussal erős kötések készíthetőek mindamellett, hogy a kis időtartam miatt a hőhatás is minimalizálódig. A cellára a már korábban említett nyomóerő tud hatással lenni. Túl nagy fellépő erő esetén olyan alakváltozások léphetnek fel, amely következtében az elektróda nagyobb felületen fog felfeküdni és ezáltal több hőt lesz képes 
bejuttatni a darabba, így nem megfelelö kötést hoz létre. Ezektöl eltekintve azonban a cellára káros hatást nem gyakorol $[8,14]$.

\section{Ellenállás ponthegesztés elektródáinak sajátosságai}

Az elektród kialakításokkal M. Masomtob és munkatársai is foglalkoztak. Vizsgálataik során három különböző kialakítást hasonlítottak össze úgy, hogy figyelemebe vették az oxidációt, a fröcskölést és az elektróda csúcsának geometriáját. Az általuk vizsgált geometriai kialakítások a lapos, a kúpos és a gömbsüveg végüek, amelyek a 6. ábrán láthatóak [15].

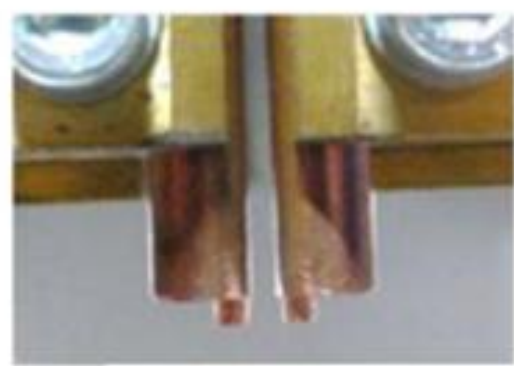

a) Lapos felületü
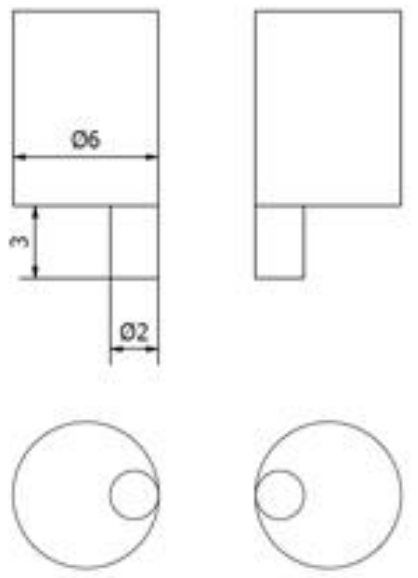

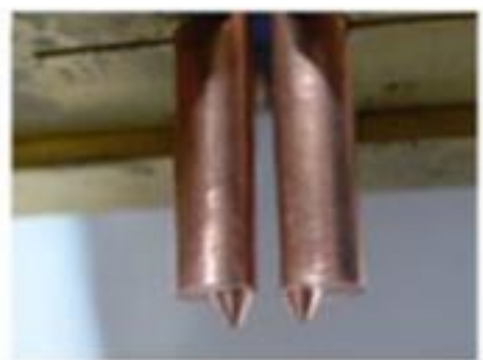

b) Kúpos felületũ
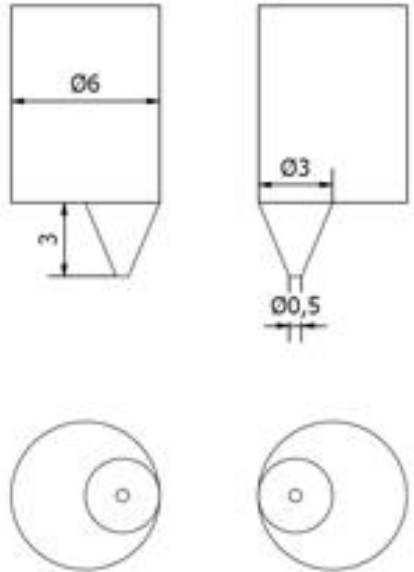

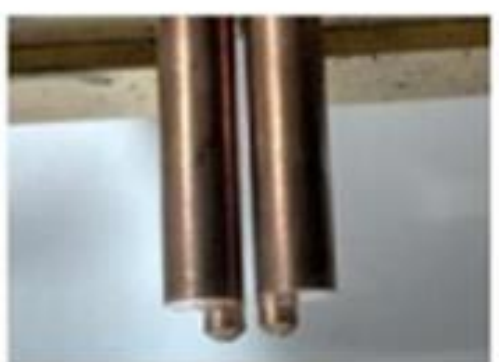

c) Körives felületũ
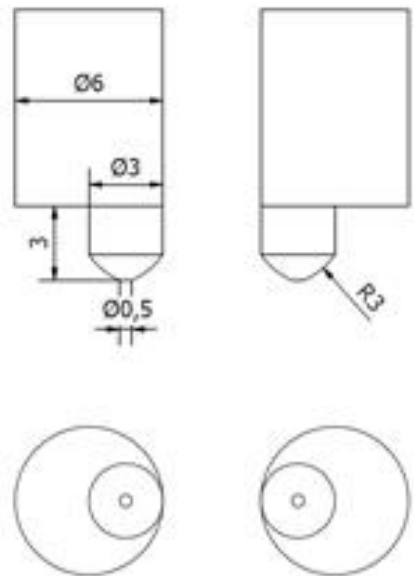

6. ábra: A kísérletekhez használt elektróda kivitelek [15]

A vizsgálataik során kötéseket készítettek mind egyen és mind váltóárammal. Megfigyelték azt, hogy egyenáram esetén az egyik kötés mérete a másikénál kisebb kiterjedéssel rendelkezik, míg váltakozó esetén szinte egyenlőek. Ezzel párhuzamosan jöttek rá arra is, hogy mivel az előbbi esetben csak egy irányban történik áramlás az egyik elektróda nagyobb hőterhelésnek lesz kitéve és ezáltal aszimmetrikus kopás következik be. A váltakozó áram esetén ez a hatás minimalizálható [15].

A lapos elektróda az egyik legegyszerübb kialakítás. Relatív nagy felfekvő felülettel rendelkezik, amelyből kifolyólag az áramsürüség a többi kialakításhoz képest sokkal alacsonyabb és ezért ugyan akkora áramerősséggel nem lehet vele megfelelő minőségü kötést létrehozni [15].

A kúpos kialakítású elektródák segítségével nagyon kis kontakt felülettel tudunk kötéseket létrehozni, amely a nagy áramsürüség következtében nagyobb hőmérsékletet és ezáltal nagyobb kötési szilárdságot eredményez. Az elektródák nagyobb hőterhelése azonban gyorsabb mértékü kopáshoz vezet [15].

A rádiuszos kialakítású elektródok, homlokfelülete minimálisan le van simítva, hasonlóan jó kötési tulajdonságokat képes elérni úgy, hogy a tönkremenetelig elvégzett müveletek száma az előző többszöröse. Emiatt a tulajdonsága miatt a tömeggyártásban ez a preferált kialakítás. Hátránya azonban, hogy az elektróda végének kialakítása CNC megmunkálással történik a 
bonyolult geometria miatt. Az előzőekben ismertetett elektródák esetén fellépő felületi hőmérsékletek eloszlását mutatja be a 7. ábra [15].
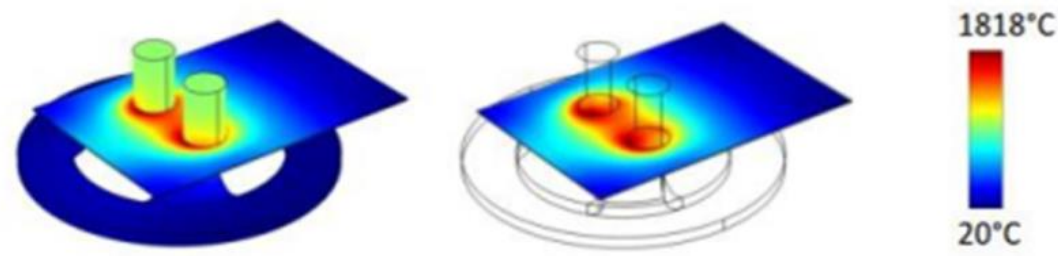

a) Lapos felületü
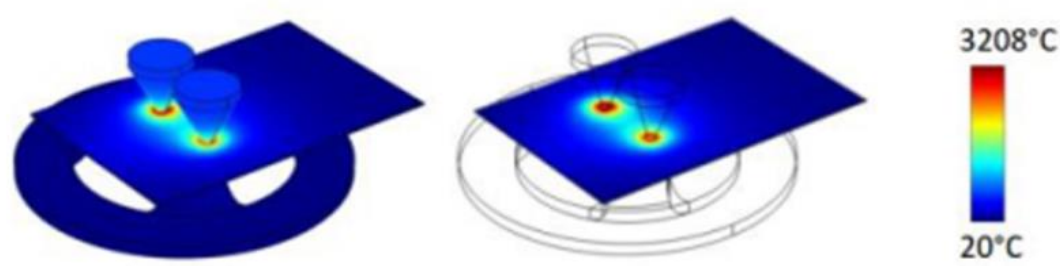

b) Kúpos felületú
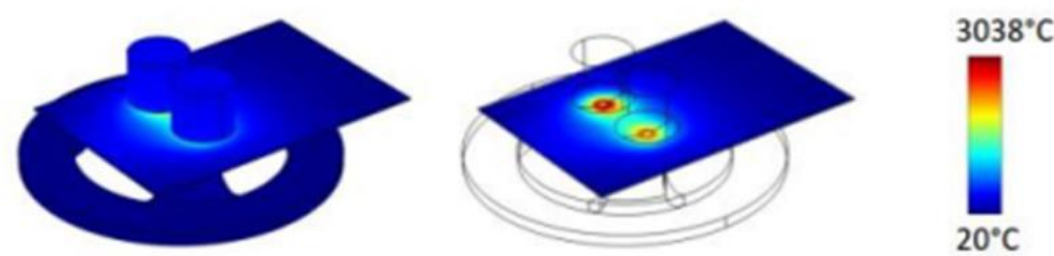

c) Köríves felületű

7. ábra: A különböző elektródák esetén fellépő hőmérsékletek és azok eloszlása [15]

Az elektróda távolságok hatásait is vizsgálta Manop Masomtob és kutató csapata. Két dolgot figyeltek meg. Az egyik, hogy a felületi deformáció mértéke nagyobb abban az esetben, ha közelebb helyezkednek el egymáshoz az elektródák. A másik pedig, hogy a cella negatív pólusán észrevehetően nagyobb elváltozás történik, amely az akkumulátor felépítéséből adódik [15].

A nagyobb deformáció jelenléte nem csak amiatt elkerülendő, hogy esetlegesen a cella maradó fizikai sérülést szenved el, hanem a kötési tulajdonságokra is negatív hatást képes kifejteni. A felületen fellépő deformáció mértékét a 8 . ábra mutatja be [15]. 


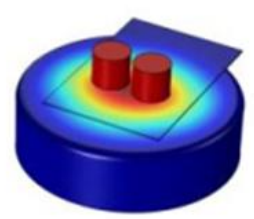

Elektródák 3,5 mm-re

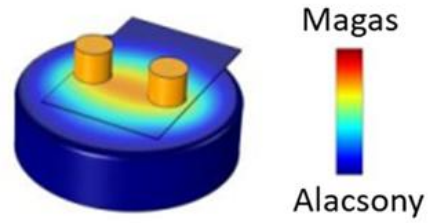

Elektródák 6,5 mm-re

(a) 3D modellek

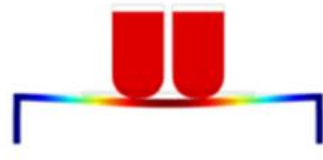

Elektródák 3,5 mm-re

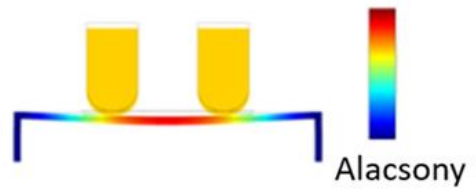

Elektródák 6,5 mm-re

\section{8. ábra: A felületi deformáció mértéke különbözö elektróda távolságok esetén [15]}

YongBing Li és munkatársai végeselemes módszer segítségével vizsgálták azt, hogy a csonka kúp végü elektróda esetén a csúcsnál mérhető szög, hogyan fogja befolyásolni a folyamatot és annak eredményét. Ennek során $15^{\circ}, 30^{\circ}, 45^{\circ}, 60^{\circ}$-os kialakításokat hasonlítottak össze. Méréseik eredményéből kiderült az, hogy az elektródák szögeinek növekedésével a felfekvő felületen egyre nagyobb hő generálódik, így jobban felmelegszik a folyamat során. Ezt figyelembe véve arra a következtetésre jutottak, hogy a kisebb szög jobb hütő hatása révén hosszabb élettartammal is rendelkezik. A jobb hőelvonó képességének azonban ára van, mégpedig az, hogy a kis szög megléte esetén kisebb kötésméret érhetö el [16].

A feltételezéseik validálása érdekében ugyanolyan paraméterek mellet ugyanolyan anyagot hegesztettek a forgácsolt elektródákkal. A felvetésük pedig igaznak bizonyult, mivel a mérésekből jól látszódik, hogy a szög csökkenésével az elvégezhető kötések száma folyamatosan növekszik. $A$ mérési eredményeket az 9. ábra szemlélteti.

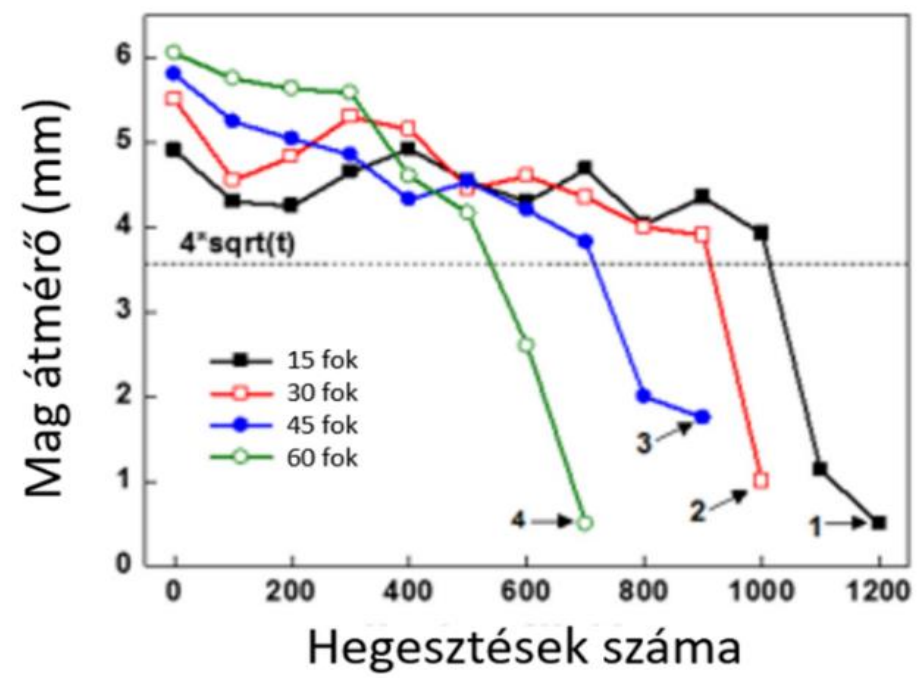

9. ábra: Az elvégezhető hegesztések száma a kritikus kötésméret eléréséig [16]

A 9. ábrán látható $4 * \operatorname{sqrt}(\mathrm{t})$ a kritikus méretet, míg a képletben található „t” betű a hegesztett lemez vastagságát jelöli.

Ezen kialakítás egy másik lehetséges megközelítése, amelyet Titus Bitek Watmon és munkatársai vizsgáltak. Azt mondták, hogy nem az elektróda szögén változtatnak, hanem a meglévőbe egy üreget helyeznek, amelyet kaolinnal és agyaggal töltenek fel és megvizsgálják a változásokat [17]. 
A tömör és töltött elektróda összehasonlítására a hegesztési áram, a hegesztési idö és a nyomóerő által kialakított hegesztési mátrixot vették alapul. Ezen belül a hegesztő áram $1 \mathrm{kA}$-es lépcsőkkel $6 \mathrm{kA}$-tól $10 \mathrm{kA}$-ig, a leszorító erő 0,5 kN-os lépcsőkkel $2 \mathrm{kN}$-tól $4 \mathrm{kN}$-ig és a hegesztési idő 5 periódusos lépcsőkkel 5-től 25-ig változott [17].

A vizsgálataik kiértékelése során pedig arra az eredményre jutottak, hogy a töltött elektródákkal bármely paramétert változtatták jobb kötésszilárdságot voltak képesek elérni a tömör réz ötvözethez viszonyítva. Ezt alátámasztandó a 10. ábrán a szakítóerő alakulása látható a nyomóerő függvényében [17].

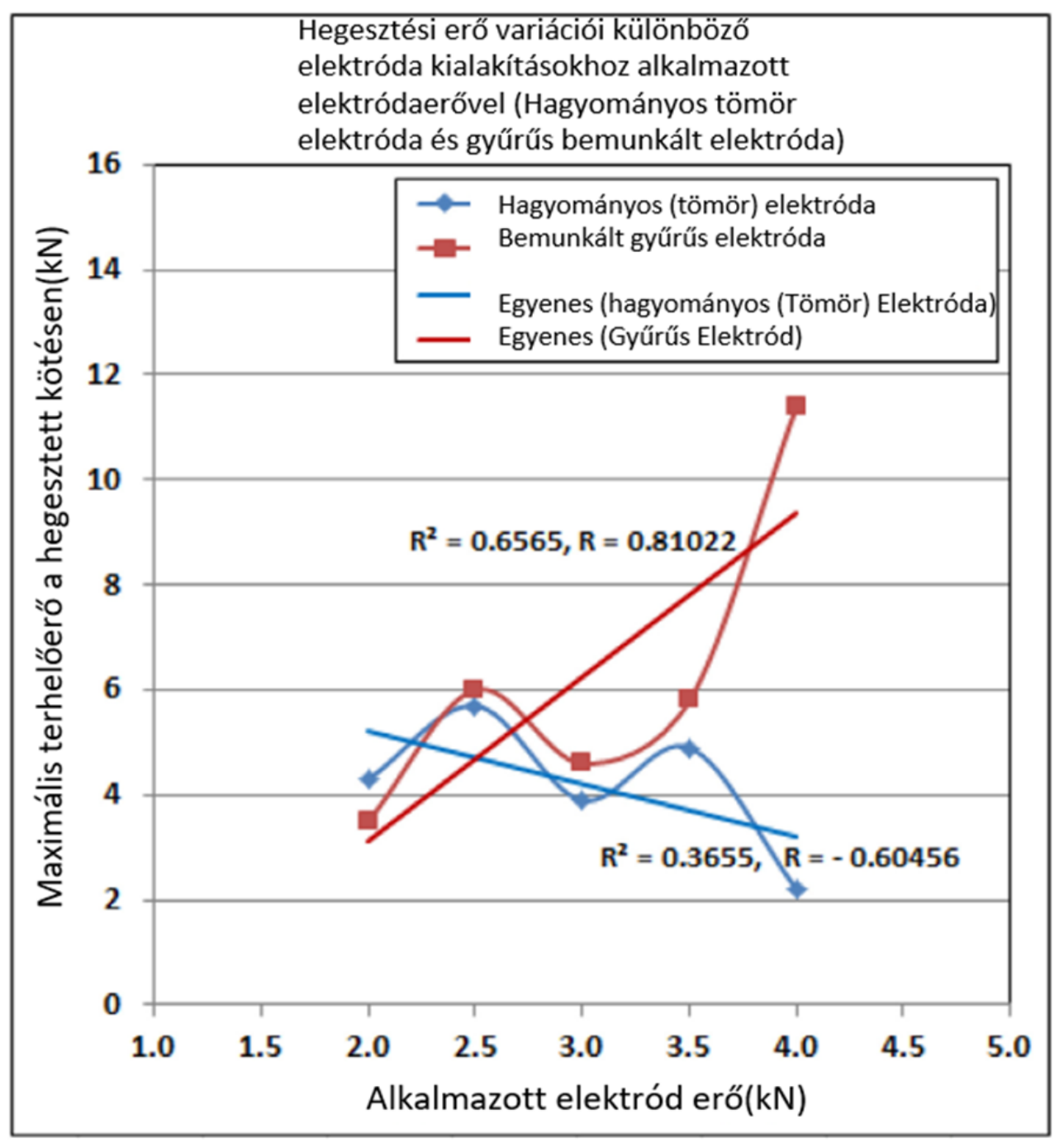

10. ábra: A szakitóerő alakulása a nyomóerő függvényében [17]

Az itt alkalmazott módszer azonban kisebb átmérőjü elektródák esetén a méretek miatt nem alkalmazható.

\section{Összegzés}

Összegzésként elmondható, hogy az akkumulátor cellák hegesztéssel történő kötésére több eljárás eredményesen alkalmazható. Különösképpen az ellenállás hegesztést kiemelve láthatjuk, hogy a technológia sajátosságaiból adódóan az elektródák kialakítása mennyiben befolyásolja a kialakuló kötés tulajdonságait. Automatizáláskor fontos az elektródák élettartama és azok folyamatos megújítása, ugyanis csak ezzel lehet biztosítani az azonos kötési minőséget. 


\section{Köszönetnyilvánítás}

A dokumentum a 2019-1.1.1-PIACI-KFI-2019-00509 pályázati azonosítószámú és „Akkumulátor pakk konstrukció fejlesztés és univerzális szerelősor fejlesztés a VIDEOTON ElektroPLAST Kft-nél" című projekt keretében készült.

\section{Irodalomjegyzék}

[1] M.F.R. Zwicker, M. Moghadam, W. Zhang, C.V. Nielsen: Automotive battery pack manufacturing -a review of battery to tab joining, Journal of Advanced Joining Processes, 2020, Volume 1, 1000172020, DOI: 10.1016/j.jajp.2020.100017

[2] Abhishek Das, Dezhi Li, David Williams, David Greenwood: Weldability and shear strength feasibility study for automotive electric vehicle battery tab interconnects, Journal of the Brazilian Society of Mechanical Sciences and Engineering, 2019, 41:54 DOI: 10.1007/s40430-018-1542-5

[3] Abhishek Das, Dezhi Li, David Williams, David Greenwood: Joining Technologies for Automotive Battery Systems Manufacturing, World Electric Vehicle Journal, 2018, 9, 22, DOI: 10.3390/wevj9020022

[4] Martin J. Branda, Elisabeth I. Kolpa, Philipp Berga, Tobias Bachb, Philipp Schmidtc, Andreas Jossena: Electrical resistances of soldered battery cell connections, Journal of Energy Storage, 2017, 12, 45-54 DOI: 10.1016/j.est.2017.03.019

[5] Dr. Balogh András-Dr. Lukács János- Dr. Török Imre: Hegeszthetőség és a hegesztett kötések tulajdonságai, 2015, Miskolc, p.: 60-134

[6] Nicolas von Drachenfels Philipp Engels, Jana Husmann, Felipe Cerdas, Christoph Herrmann: Scale-Up of Pilot Line Battery Cell Manufacturing Life Cycle Inventory Models for Life Cycle Assessment, Procedia CIRP, 2021, Volume 98, Pages 13-18DOI: 10.1016/i.procir.2020.12.002

[7] Dr. Szunyogh László: Hegesztés és rokon technológiák kézikönyv, Budapest, 2007

[8] Harald Larsson, Alec Chamberlain, Sally Walin, Samir Schouri, Louise Nilsson, Elin Myrsell, Daniel Vasquez: Welding methods for electrical connections in battery systems Uppsala Universitet 2019

[9] Philips D.H. Welding Engineering: An Introduction. New York: John Wiley \& Sons; 2015. 5, High Energy Density Welding Processes; p. 114-22.

[10] Amada Miyachi. Fiber Laser Welding. [Cited date 2019-05-15] Webes cím: https://www.amadamiyachi.eu/knowlegde-base/fiber-laser-welding

[11] EBindustries. CW and Pulsed Laser Welding. [Cited date 2019-05-15] Webes cím: https://www.ebindustries.com/cw-and-pulsed-laser-welding/

[12] Manop Masomtob, Rawitat Sukondhasingha, Jan Becker, and Dirk Uwe Sauer: Parametric Study of Spot Welding between Li-ion Battery Cells and Sheet Metal Connectors, Engineering Journal Volume 21 Issue 72019

[13] YongBing Li,ZeYu Wei, YaTing Li, Qi Shen, ZhongQin Lin: Effect of cone angle of truncated electrode on heat and mass transfer in resistance spot welding International Journal of Heat and Mass Transfer 2013

[14] Titus Bitek Watmon, Catherine Wandera, James Apora: Characteristics of resistance spot welding using annular recess electrodes Journal of Advanced Joining Processes 2020

[15] Manop Masomtob, Rawitat Sukondhasingha, Jan Becker, and Dirk Uwe Sauer: Parametric Study of Spot Welding between Li-ion Battery Cells and Sheet Metal Connectors, Engineering Journal Volume 21 Issue 72019

[16] YongBing Li,ZeYu Wei, YaTing Li, Qi Shen, ZhongQin Lin: Effect of cone angle of truncated electrode on heat and mass transfer in resistance spot welding International Journal of Heat and Mass Transfer 2013

[17] Titus Bitek Watmon, Catherine Wandera, James Apora: Characteristics of resistance spot welding using annular recess electrodes Journal of Advanced Joining Processes 2020 